Alicja Sobańska

(Biblioteka Raczyńskich, Poznań)

a.sobanska.also@gmail.com

\title{
Oddział Opracowywania Multimediów Biblioteki Raczyńskich w Poznaniu - struktura, zadania, baza programowa
}

Biblioteka Raczyńskich jest miejską książnicą wpisaną w przestrzeń Poznania od 188 lat. Jedną ze statutowych dyrektyw jej fundatora - Edwarda Raczyńskiego - było to, by korzystać mógł z niej „każdy, bez różnicy osób” ${ }^{1}$ $\mathrm{i}$ to oświadczenie woli także w obecnych warunkach jest respektowane i ma oczywiste uzasadnienie. Czytelnikiem czy też użytkownikiem Biblioteki Raczyńskich może zostać każdy, kto wyrazi taką wolę i w fizycznej strefie Biblioteki respektować będzie zgodne z regulaminem ogólnie przyjęte zasady kultury osobistej.

Podobnie jak inne tego typu placówki, także Biblioteka Raczyńskich stara się wychodzić naprzeciw potrzebom i wymogom współczesności, tak by stworzyć dla potencjalnych odbiorców przestrzeń gwarantującą nie tylko kontakt z lepiej lub gorzej dostępną gdzie indziej literaturą naukową czy beletrystyczną, ale również z tym obszarem ludzkiej aktywności, który określić można mianem sfery socjalizacyjnej, kulturotwórczej czy wręcz sfery rozrywki. Pod względem organizowanych przedsięwzięć będą to: różnorodne spotkania tematyczne, szkolenia, wykłady, wystawy, pod kątem udostępnianych zbiorów - materiały zapisane na nośniku innym niż papier.

Truizmem jest oczywiście stwierdzenie, że dzisiejsze biblioteki to nie tylko miejsca, w których wypożycza się książki. Szerokopasmowy Internet, odpowiednio zaaranżowana strona internetowa, obecność na portalach społecznościowych to dziś warunek sine qua non współczesnej biblioteki. Coraz częściej dzisiejszemu konsumentowi przychodzi odwiedzać mediateki, gdzie dostęp do interaktywnych dokumentów elektronicznych, filmów na DVD,

${ }^{1}$ Zob. par. 3. Statutu Biblioteki Raczyńskich, rękopis przechowywany w Dziale Zbiorów Specjalnych Biblioteki Raczyńskich, sygn. Rkp. 124. 
audiobooków czy muzycznych płyt CD jest oczywistością. Niepojedynczo, by być w zgodzie z duchem czasu, biblio- czy mediateki oferują możliwość korzystania z gier czy programów edukacyjnych ${ }^{2}$, a także wprowadzają np. usługi wypożyczeń czytników e-booków. Wszystkie te czynności przebiegać muszą w zsynchronizowanym współudziale agend gromadzenia, opracowania i udostępniania zbiorów.

Wprawdzie Biblioteka Raczyńskich dotychczas nie wprowadziła opcji wypożyczania czytników e-booków, zasadniczo nie zakupuje też gier komputerowych ${ }^{3}, \mathrm{w}$ swych zasobach mieści natomiast bogatą filmotekę, stale uzupełniany zasób audiobooków oraz kolekcję nagrań muzycznych, przede wszystkim na płytach CD, ale także DVD. Opracowaniem tego zbioru zajmują się pracownicy powstałego z początkiem 2013 r. Oddziału Opracowania Multimediów - podjednostki Działu Gromadzenia i Opracowania Zbiorów.

\section{Oddział Opracowania Multimediów Biblioteki Raczyńskich}

\section{Struktura nadrzędna}

Plan powołania nowej jednostki w obrębie opracowania zbiorów pojawił się wraz z perspektywą uwieńczenia rozbudowy Biblioteki Raczyńskich i przeniesienia strukturalnych jednostek bibliotecznych z budynku przy ul. Święty Marcin do nowego gmachu w Alejach Marcinkowskiego, co ostatecznie miało miejsce w czerwcu 2013 r. By w nowej siedzibie personel był już profesjonalnie wprawiony do wykonywania swych (ewentualnie) nowych obowiązków, a narastający zasób zbiorów przygotowany do udostępnienia, restrukturyzacja miała miejsce odpowiednio wcześniej ${ }^{4}$. Dotyczyła ona zresztą wszystkich jednostek na osi gromadzenie - opracowanie - udostępnianie i przeprowadzona została w taki sposób, że z jednej strony mówić można o procederze ich scalenia, z drugiej - wyodrębnienia. Z funkcjonującego dotychczas oddzielnie Działu Informacyjno-Bibliograficznego i Działu Udostępniania Zbiorów utworzono jeden Dział Informacji i Udostępniania Zbiorów, podobnie odrębny Dział Gromadzenia i Dział Opracowania ustrukturyzowano w jeden Dział Gromadzenia i Opracowania Zbiorów, wydzielając w nim funkcjonujące już wcześniej bądź całkiem nowe oddziały. O ile podjednostki z pierwotnego Działu Gromadzenia Zbiorów zostały bez przekształceń przeniesione

2 Por. publikację przygotowaną w ramach Programu Rozwoju Bibliotek: A. Hejda, P. Szczęsny, A. Habis, Aktywna biblioteka. Multimedia i nowoczesna komunikacja, Warszawa 2010, https:/ / issuu.com/publikacjefrsi/docs/nowowczesna-komunikacja (dostęp 10 czerwca 2017).

${ }^{3}$ Pojedyncze ich egzemplarze mogą się pojawić jako element składowy multimediów interakcyjnych, zwykle dołączanych do czasopism w postaci dokumentów elektronicznych na płycie CD lub DVD, albo też jako materiał dodatkowy filmów.

${ }^{4}$ W styczniu $2013 \mathrm{r}$. 
w nowe struktury (Oddział Czasopism, Oddział Zakupu, Oddział Ubytków, Oddział Darów), o tyle w Dziale Opracowania przeprowadzone zostały dość istotne zmiany. Zlikwidowano w nim wyodrębniony wcześniej podział na opracowanie tzw. Działu Sieci Bibliotecznej (przygotowywano tu rekordy dla zbiorów trafiających do punktów filialnych) i opracowanie tzw. księgozbioru podstawowego (KP), udostępnianego pierwotnie w budynku głównym przy Świętym Marcinie. W to miejsce wprowadzono natomiast cztery oddziały ze ściśle określoną, przyporządkowaną oddziałowi liczbą pracowników (Oddział Opracowania Druków Zwartych, Oddział Opracowania Literatury Dziecięcej, Oddział Opracowania Multimediów i Oddział Retrokonwersji).

Taka restrukturyzacja oznaczała przede wszystkim specjalizację, a co za tym idzie konieczność w pełni profesjonalnego opanowania zasad katalogowania wąskiego typu dokumentów. Dotychczas w obrębie działu opracowywano zarówno beletrystykę, jak i filmy, tak audiobooki, jak i literaturę naukową ${ }^{5}$, teraz osoba przypisana do Oddziału Retrokonwersji nie miała mieć już zawodowej styczności z nowościami wydawniczymi, a pracownik Oddziału Opracowania Druków Zwartych z oddzielnie wydanym filmem. W specyficzny sposób zmianę tę odczuli katalogerzy Oddziału Opracowania Multimediów, którzy przyzwyczajeni w swej dotychczasowej pracy do ciągłego kontaktu z książką drukowaną, w aspekcie zawodowych obowiązków - opracowania zbiorów, całkowicie stracili z nią kontakt. Znamieniem Oddziału była także pewna trudność, z którą musieli zmierzyć się jego pracownicy, nieobecna $\mathrm{w}$ takim stopniu $\mathrm{w}$ innych jednostkach Opracowania, a związana z koniecznością stworzenia nierzadko od podstaw własnej metodyki pracy. Wynikało to $\mathrm{z}$ faktu, iż zasady opracowania przypisanych do Oddziału zbiorów należą do tych, które cechuje duża wariantywność, a co za tym idzie stosunkowo niska frekwencja bezwyjątkowych reguł ${ }^{6}$.

Konsekwencją tego stanu rzeczy jest fakt istnienia rozbieżności w sposobie opisów analogicznych dokumentów w obrębie jednej biblioteki i nierzadko ewidentne różnice $\mathrm{w}$ opisach tych samych pozycji w skali całego kraju. Innymi słowy, przystępując do prac w nowo utworzonym Oddziale Opracowania Multimediów zdawano sobie sprawę, że w wielu przypadkach Biblioteka Raczyńskich nie znajdzie autorytatywnego wzorca, na którym mo-

\footnotetext{
${ }^{5}$ Można wprawdzie mówić o istniejącej już wcześniej praktyce specjalizacji i przypisaniu konkretnych osób do opracowania poszczególnych zbiorów (przez pewien czas np. filmy katalogowała jedna, może dwie osoby), ale była to reguła nieformalna, oparta o preferencje katalogerów bądź potrzeby działu; w zasadzie każdemu mógł przypaść do opracowania każdy typ publikacji. Wyjątkiem była literatura dziecięca - od początku tą grupą zbiorów zajmowały się w Dziale Opracowania jedynie przypisane jej osoby, które poza tym nie katalogowały innych zbiorów.

${ }^{6}$ Podyktowane jest to nierzadko zresztą taką a nie inną praktyką wydawniczą, którą rekord opisu w jakiś sposób odzwierciedla.
} 
głaby się oprzeć bezwzględnie na każdym etapie opracowania dokumentu, że niejednokrotnie przyjdzie jej pracownikom wyznaczyć własne, autorskie rozwiązania, oraz że nie obędzie się bez przeprowadzenia głębokich melioracji katalogu, tak w celu skorygowania błędów w następstwie wprowadzenia zmian zewnętrznych (pojawiających się co jakiś czas aktualizacji zasad ogłaszanych przez środowiska mające w skali kraju moc decyzyjną - Bibliotekę Narodową i Narodowy Uniwersalny Katalog Centralny NUKAT), jak i wewnętrznych, ustalonych w środowisku wewnątrzdziałowym.

\section{Zespół}

Od początku istnienia Oddziału Opracowania Multimediów przewidziano dla niego trzy stanowiska pracownicze i w takim składzie rozpoczęto $\mathrm{w}$ nim prace. Był to czas szczegółowego zaznajamiania się z istniejącymi standardami, śledzenia pojawiających się korekt, nowel, uaktualnień. Wprawdzie całą przypisaną do Oddziału kolekcję - zbiory na nośniku cyfrowym: muzykalia, filmy, audiobooki i mieszczące różne formaty danych tzw. dokumenty elektroniczne - wcześniej już katalogowano ${ }^{7}$, ale były to wówczas zbiory bardziej rozproszone, a w świadomości pracowników funkcjonowały w tamtym czasie jako pomniejszy, by nie rzec znikomy zbiór w kontekście całości bieżącego, należnego do opracowania zasobu ${ }^{8}$.

Polityka gromadzenia z wytyczoną perspektywą zwiększania nakładów na zbiory multimedialne, powiększająca się liczba filii oferujących ten typ kolekcji, nadto przystąpienie do sporządzania retrokonwersji płyt CD z filii muzycznej (F61), dawały pewność, że pracy będzie pod dostatkiem ${ }^{9}$.

Postanowiono, iż wszystkie osoby w Oddziale będą katalogować każdy typ dokumentu i to całościowo - $\mathrm{w}$ aspekcie formalnym i rzeczowym (nie

${ }^{7}$ Stosując się do już istniejących ustandaryzowanych zasad opracowania. Instrukcjami tymi są następujące pozycje książkowe (wraz z uaktualnieniami i przepisami szczegółowymi): A. Drożdż, M. Stachyra, Format MARC 21 rekordu bibliograficznego dla dokumentu dźwiękowego, Warszawa 2002; K. Sanetra, Format MARC 21 rekordu bibliograficznego dla dokumentu elektronicznego, Warszawa 2003; K. Sanetra, Format MARC 21 rekordu bibliograficznego dla filmu, Warszawa 2008.

${ }^{8}$ Wspomnieć należy raz jeszcze o kolekcji filmów, która już wcześniej przypisana była do opracowania zasadniczo jednemu pracownikowi. Osoba ta w czasie zbliżonym do przeprowadzonej restrukturyzacji odeszła na emeryturę.

${ }^{9}$ Obecnie rozkład nabytków multimedialnych kształtuje się w Bibliotece Raczyńskich następująco: filmy udostępniane są w siedemnastu filiach i w centralnej wypożyczalni (CW), audiobooki - w 24 filiach i w CW, muzyka - w dwóch filiach (w tym w filii specjalistycznej) i w CW, dokumenty elektroniczne - w czytelni multimedialnej. Filmy, audiobooki i płyty z nagraniami muzycznymi przygotowywane są także do filii zlokalizowanej w Naramowicach, dotychczas jeszcze nieotwartej. Oczywiście praca katalogera zawęża się do wykonania opisu odrębnych jednostek wydawniczych, a nie ich poszczególnych egzemplarzy, co oznacza, że jeden rekord opisu zawierać może wiele rekordów pozycji, w zależności od tego, ile sztuk danego egzemplarza wydawniczego znajduje się w zbiorach biblioteki. 
wprowadzono specjalizacji), by ze względu na niewielki skład kadrowy nie stwarzać powodu do przestoju $\mathrm{w}$ pracy $\mathrm{w}$ razie ewentualnej nieobecności; miało to też uchronić przed możliwą rutynizacją.

Ramowy zakres obowiązków pracownika Oddziału Katalogowania Multimediów obejmuje następujące czynności:

- ustalanie w bazie modułu katalogowania faktu istnienia bądź nieistnienia właściwego rekordu opisu,

- sporządzanie rekordów opisu bibliograficznego dokumentów elektronicznych, dźwiękowych i filmów (bieżący wpływ i retrokonwersja),

- pobieranie rekordów z dostępnych baz,

- dokonywanie korekt opisów błędnych bądź skatalogowanych wedle nieaktualnych zasad,

- prowadzenie własnych statystyk pracy,

- odpowiedzialność za określoną część zbiorów opracowywaną w danym czasie,

- wykonywanie prac zleconych przez kierownika i dyrekcję.

W Oddziale panuje praktyka wymiany doświadczeń katalogowych $\mathrm{w}$ przypadku pojawienia się skomplikowanej lub nietypowej pozycji do opracowania, na bieżąco dyskutuje się też ogólne kwestie problemowe i ustala optymalne rozwiązania w oparciu o normy i standardy. Każdy z pracowników ma dostęp do obowiązujących instrukcji, materiałów metodycznych i wszelkiego typu potrzebnych dokumentów. Pracownicy starają się też wzajemnie informować o ciekawych źródłach (głównie internetowych), które mogą wzbogacić warsztat pracy katalogera, w miarę możliwości korzystają też z warsztatów i szkoleń.

\section{Obieg zbiorów}

Rekord opisu przygotowuje się w Oddziale z autopsji, co oznacza, że do jego sporządzenia potrzebny jest fizyczny kontakt z katalogowanymi zbiorami. Do stanowisk katalogerów docierają one na kilka sposobów. Zakupione nowości trafiają z sąsiedniego Oddziału Gromadzenia pojedynczo lub w całości partii zakupu wraz z fakturą i po opracowaniu oraz naklejeniu na każdy nośnik kartki z wygenerowanym komputerowo numerem opisu odsyłane są powrotnie do Gromadzenia, gdzie podlegają dalszym procedurom, włącznie z wysyłką do docelowych agend. Katalogerzy muszą mieć także na uwadze, by sprawdzić liczbę sporządzonych rekordów z liczbą pozycji na fakturze (ze względu na zasady katalogowania nie zawsze musi być to stosunek jeden do jednego).

Pojedyncze egzemplarze przynoszone osobiście przez pracowników filii (nowości zakupione za pieniądze czytelników z należności za zbyt długie przetrzymywanie zbiorów, dary, pozycje do retrokonwersji) opracowywane są albo na bieżąco i bezpośrednio odbierane, albo - co jest częstszym proce- 
derem - są przyjmowane „do kolejki” i następnie (już po sporządzeniu rekordu opisu) odkładane na specjalnie przygotowane regały, skąd pracownicy filii odbierają je przy następnej obecności w Opracowaniu. Większe partie do retrokonwersji przywożone są z filii bibliotecznych w zaklejonych i zabezpieczonych przed uszkodzeniem kartonach i po opracowaniu odkładane bezpośrednio do transportu, po uprzednim ponownym oklejeniu i zabezpieczeniu kartonu. W przypadku filii ze zbiorami muzycznymi (F61) konieczne jest uzupełnienie wykazu otrzymanych do retrokonwersji jednostek o właściwe numery opisów bibliograficznych i zwrotne przesłanie uzupełnionego dokumentu drogą mejlową.

Materiały multimedialne dołączane do czasopism trafiają z Oddziału Czasopism już z przyporządkowanym numerem inwentarzowym oraz sygnaturą i po opracowaniu przekazywane są do czytelni multimedialnej.

Wybór kolejnych pozycji do opracowania przebiega zasadniczo w trybie następczym, zgodnie z kolejnością dostarczenia, choć nowości mają pierwszeństwo przed zbiorami przeznaczonymi do retrokonwersji; także zwykle egzemplarze przeznaczone do centralnej wypożyczalni katalogowane są w pierwszej kolejności. Pracownicy Oddziału starają się zachować poprawne stosunki koleżeńskie, są elastyczni i w miarę możliwości dostosowują się do sugestii kolejności opracowania, podyktowanych niezależnymi czynnikami, np. terminami wywózki na filie.

Jeśli nie ma naglącej sytuacji, która zmuszałaby do możliwie najszybszego opracowania całego przekazu i co za tym idzie - zaangażowania wszystkich pracowników, zasadniczo pracę dobiera się tak, by w całości samodzielnie skatalogować daną partię zbiorów ${ }^{10}$. Taki tryb wydaje się dobrze wypracowanym schematem organizacyjnym, sprzyja poczuciu samodzielności i względnej autonomii wykonywanej pracy, nadto umożliwia kontrolę nad daną wyszczególnioną partią zbiorów i w razie czego wzięcie za nią odpowiedzialności.

Nie ma ściśle określonej dziennej normy wykonania rekordów; ze względu na fakt zróżnicowania opisów pod względem długości i skali trudności, taka wytyczna nie miałaby racji bytu. Najprostsze pozycje, stanowione zwykle przez audiobooki lub płyty CD z muzyką rozrywkową, można w całości skatalogować w ciągu kilkunastu minut, najtrudniejsze (bywa że z danymi w alfabecie niełacińskim), te, których opis wymaga szczegółowych penetracji źródłowych, utworzenia haseł wzorcowych i tytułów ujednoliconych, nawet do kilku godzin (zwykle dotyczy to płyt z tzw. muzyką poważną, gdzie każdy nagrany utwór podlega wzorcowemu rozpisaniu, lub tzw. dokumentów elektronicznych). Uśredniając, powiedzieć można, że dziennie jedna oso-

${ }^{10}$ Zwykle umieszczoną w kartonie bądź - jeśli trafia z Gromadzenia - w specjalnie przygotowanym korytku. 
ba w Oddziale Opracowania Multimediów tworzy do ok. dziesięciu rekordów opisu bibliograficznego.

\section{System biblioteczny Horizon}

Biblioteka Raczyńskich w procesie zarządzania zbiorami wykorzystuje zintegrowany system biblioteczny Horizon. Jest to jeden z wielu dostępnych programów komputerowych, umożliwiających sprawne poruszanie się w środowisku operującym tak ogromną liczbą danych, jak to ma miejsce w przypadku bibliotek. System Horizon wykorzystywany jest głównie w bibliotekach akademickich (w skali światowej raczej tych średnich i mniejszych) oraz w większych książnicach publicznych. Opiera się na strukturze pięciomodułowym: module gromadzenia z wyodrębnionym modułem wydawnictw ciągłych, module opracowania, module udostępniania i tzw. module OPAC (Online Public Access Catalog), zwanym też w tym przypadku HIP-em (Horizon Information Portal) - jest to katalog dostępny dla użytkowników przez Internet.

Implementacja programu w Bibliotece Raczyńskich w 1998 r. stała się możliwa dzięki ukonstytuowaniu się dwa lata wcześniej Poznańskiej Fundacji Bibliotek Naukowych, która w projekt komputeryzacji zbiorów bibliotecznych wpisała prócz Biblioteki Raczyńskich przede wszystkim państwowe biblioteki uczelniane Poznania ${ }^{11}$. Wdrożenie jednolitego systemu w naukowych bibliotekach miasta umożliwiło pracownikom - zwłaszcza na początku zespołowych działan - wspólne wykorzystanie bazy szkoleniowej; użytkownicy różnych typów bibliotek przywyknąć natomiast mogli do w miarę jednolitej szaty graficznej (z elementem dyferencjującym $\mathrm{w}$ postaci zastosowanej kolorystyki) katalogów OPAC.

Program Horizon, co symptomatyczne dla dotychczasowych systemów bibliotecznych, skonfigurowany jest $\mathrm{w}$ architekturze klient-serwer (oznacza to m.in., że wszystkie dane zapisywane są na serwerze), do pobierania danych z innych baz wykorzystuje protokół Z39.50 (co też powszechne) i przystosowany jest do obsługi standardowego w międzynarodowym środowisku bibliotecznym formatu MARC. Horizon, wyprodukowany przez amerykańską firmę Ameritech ${ }^{12}$, przez okres kilkunastoletniego funkcjonowania na rynku był wielokrotnie aktualizowany i jakkolwiek $\mathrm{w}$ wielu przypadkach nie jest perspektywicznie traktowany jako pierwszoklasowy system biblioteczny ${ }^{13}$, to

11 Zob.: B. Maruszewski, Poznańska Fundacja Bibliotek Naukowych, [w:] 5 lat Poznańskiej Fundacji Bibliotek Naukowych, Poznań 2001, s. 8; A. Kraszewska, Wdrażanie systemu Horizon w Bibliotece Raczyńskich, [w:] tamże, s. 39.

12 Dostawcą programu została firma Dynix, obecnie SirsiDynix.

13 Taka sytuacja ma miejsce zwłaszcza w kontekście rozwoju tzw. systemów bibliotecznych nowej (czy też następnej) generacji, określanych mianem platform usług bibliotecznych, gdzie przetwarzanie danych odbywa się w tzw. chmurze obliczeniowej (cloud computing), a same te systemy udostępniane są często $\mathrm{w}$ tzw. modelu SaaS (software as a service, oprogramowanie jako 


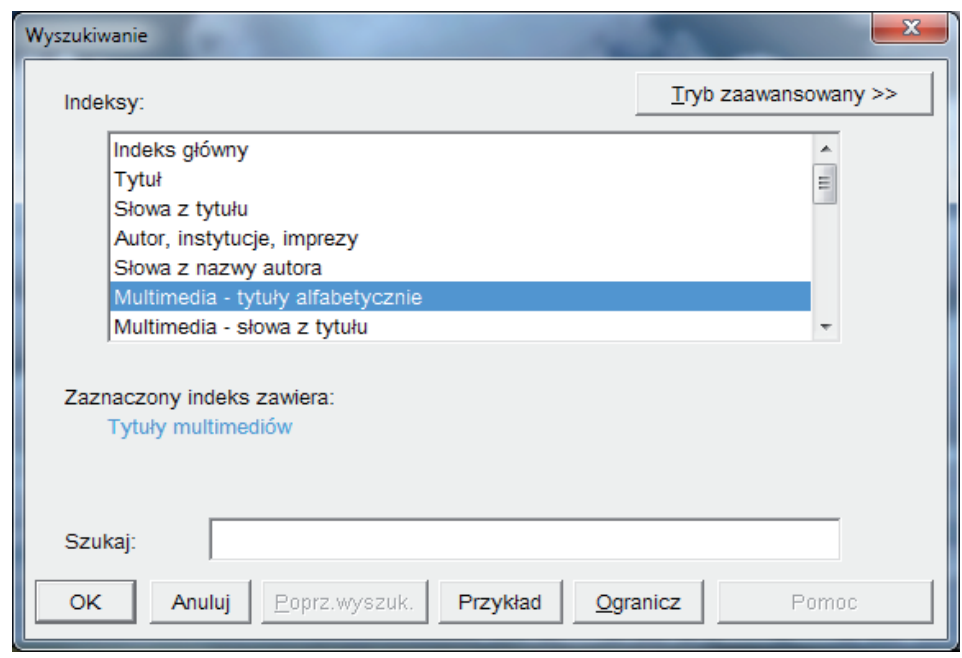

Rys. 1. Horizon - wyszukiwanie w module opracowania

jednak jego użytkowanie kojarzone jest wciąż z solidnym i poprawnym sposobem zarządzania zbiorami bibliotecznymi.

Marshall Breeding, niezależny konsultant związany z amerykańskim środowiskiem bibliotecznym, rokrocznie od 2008 r. dokonuje światowej ewalu-

usługa). Temu zagadnieniu poświęcona została np. konferencja Systemy biblioteczne nowej generacji. Platformy ustug, Gliwice, 15-16 października 2015 r. Zob. http://www.bg.polsl.pl/konf/ bawinatech/index.html (dostęp 15 czerwca 2017). Por. też R. Ciesielska-Kruczek, A. Fogla, J. Kołakowska, Systemy biblioteczne nowej generacji. Platformy ustug - sprawozdanie z konferencji Biblioteki Głównej Politechniki Ślaskiej, „Biblioteka i Edukacja. Elektroniczne czasopismo Biblioteki Głównej Uniwersytetu Pedagogicznego w Krakowie" 2015, nr 8, www.bg.up.krakow.pl/new bie/index.php/bie/article/download/126/126 (dostęp 15 czerwca 2017).

Rozpatrując kwestię osadzenia systemu Horizon w Bibliotece Raczyńskich i innych ośrodkach krajowych, nie można bagatelizować pewnych głosów krytycznych pojawiających się w środowiskach akademickich, mocą uprzednich decyzji w jakiś sposób z Biblioteką związanych. Tak np. Biblioteka Uniwersytetu im. Mikołaja Kopernika w Toruniu, od której swego czasu poznańska książnica pozyskiwała część opisów, nie zdecydowała się na przejście na nową wersję Horizona i wprowadziła własne oprogramowanie. W 2015 r. przyszłość odnośnie do korzystania z programu pod znakiem zapytania otwarcie postawili przedstawiciele Biblioteki UAM (dzielącej z Biblioteką Raczyńskich członkostwo w Poznańskiej Fundacji Bibliotek Naukowych). Analizując kwestię optymalizacji procesów bibliotecznych i dokonań w Bibliotece Uniwersyteckiej, autorzy zaznaczyli: „Niestety od pewnego czasu liczba aplikacji i skryptów zdecydowanie przerasta możliwości systemu Horizon, co rodzi pytania o przyszłość dalszej współpracy z firmą SirsiDynix, producentem oprogramowania Horizon, deklarującym usługi dla bibliotek", P. Karwasiński, H. Wesołowska-Mis, Wpływ informatyzacji Biblioteki Uniwersyteckiej w Poznaniu na zmiany organizacyjne i rozwój ustug bibliotecznych, „Biblioteka” 2015, nr 19(28), s. 166.

Jak na razie Biblioteka Raczyńskich nie powzięła decyzji o rezygnacji z systemu Horizon, choć kilkakrotnie wprowadzano kolejne wersje oprogramowania. 


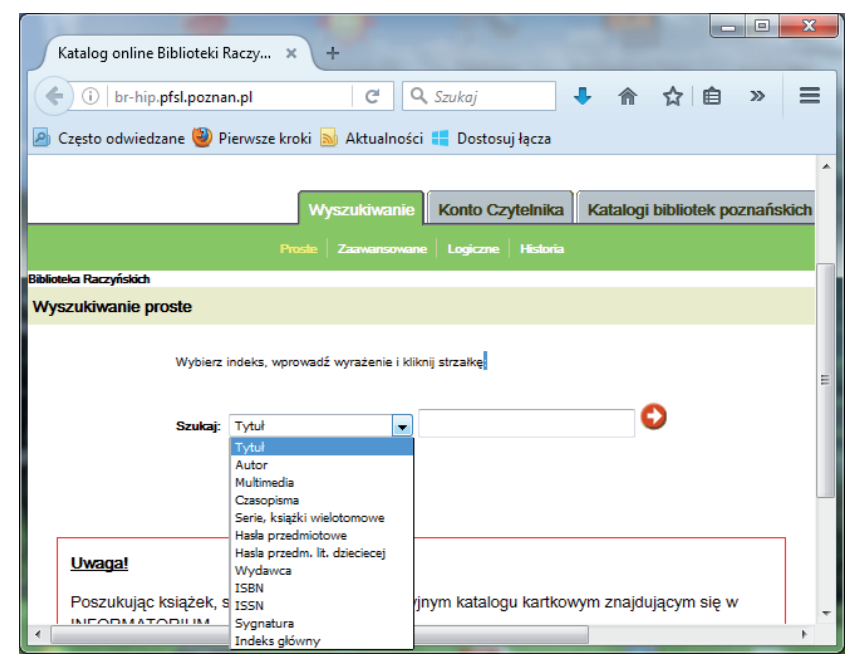

Rys. 2. Horizon - wyszukiwanie w module OPAC

acji systemów bibliotecznych $\mathrm{w}$ oparciu o specjalnie przygotowane ankiety. Jak podaje w kolejnym sprawozdaniu, w 2016 r. wypełniono je w 4042 bibliotekach 92 krajów świata, głównie z obszarów języka angielskiego. Ocenie podległo 138 różnych programów bibliotecznych pod względem różnych parametrów. Wśród dużych bibliotek publicznych najwyższe noty uzyskał system Polaris, Apollo zdobył natomiast największe uznanie w bibliotekach małych; średnie biblioteki publiczne najwyżej oceniły system Library.Solution. Wysoką ocenę w bibliotekach akademickich odnotowano dla oprogramowania Alma, a w bibliotekach szkolnych dla programu OPALS.

System biblioteczny Horizon kształtował noty na dość dobrej pozycji; tym, co zwraca uwagę, jest tendencja zwyżkowa ocen, co obserwować można wyraźnie od dwóch lat. Program został lepiej oceniony przez biblioteki publiczne niż akademickie. Funkcjonalność była znacznie wyżej punktowana pod względem zarządzania zbiorami drukowanymi niż elektronicznymi tu niskie oceny pojawiały się szczególnie ze strony przedstawicieli średnich bibliotek uczelnianych. Mniejsze biblioteki akademickie zadeklarowały za to wierność marce SirsiDynix.

Na uwagę zasługuje też fakt, że coraz mniej bibliotek korzystających z programu Horizon deklaruje chęć zmiany systemu - spośród dziewięciu wykresów przedstawiających gotowość do przejścia na nowe oprogramowanie jedynie dla użytkowników Horizona notuje się wyraźną tendencję spadkową, począwszy od roku $2010^{14}$.

14 Szczegółowe zestawienie wyników ankiety zob.: M. Breeding, Perceptions 2016: An International Survey of Library Automation, https:/ /librarytechnology.org/perceptions/2016/\#survey-details (dostęp 15 czerwca 2017). 


\section{Format MARC 21}

MARC 21 to format służący do kodowania poszczególnych elementów metadanych, na które składa się opis bibliograficzny w takiej formie, by był on czytelny dla maszyny. Jest jednym z najbardziej popularnych struktur z klasy MARC (Machine-Readable Cataloging), wykorzystywanym w bazach katalogowych i bibliograficznych całego świata. Obrazowo przedstawić można go jako ustrukturyzowany szkielet, na który nanizane zostają dane służące identyfikacji katalogowanego obiektu w procesie sporządzenia rekordu opisu bibliograficznego. Jest tą przestrzenią, w której odbywa się codzienna praca katalogera. Format MARC 21 jest niezależny od platformy, co oznacza, że można go zaimplementować do różnego typu oprogramowania, w tym oczywiście do Horizona.

Historia formatu sięga połowy lat 60 . ubiegłego wieku ${ }^{15}$. W końcu lat 90. XX w., i w perspektywie wejścia w nowy wiek, ogłoszono ustandaryzowaną wersję - MARC 21, która stała się dominującym formatem rekordów bibliograficznych sporządzanych pod każdą szerokością geograficzną. Format MARC 21 jest strukturą o ściśle określonych parametrach, w której elementy takie, jak: pola, podpola, wskaźniki i etykiety, odgrywają istotną rolę, umożliwiając uszeregowanie i właściwe odczytanie danych przez komputer. Jakkolwiek fakt prawie dwudziestoletniego, niemal powszechnego wykorzystywania MARC-a $21 \mathrm{w}$ procesie przetwarzania informacji i tworzenia komputerowych opisów bibliograficznych świadczy o jego niekwestionowanej pozycji (ciągle aktualnej!), to jednak zasadniczo w kręgach specjalistów z formatem tym nie łączy się świetlanej przyszłości. Już w 2002 r. Roy Tennant tytułem swego artykułu orzekał: MARC Must Die (MARC musi umrzeć) ${ }^{16}$. Jarosław Pacek pisze wprost: "[...] kwestie finansowe przesądzają o tym, że nie jest on [MARC 21 - przyp. A.S.] jeszcze masowo wypierany przez inne, bardziej elastyczne i przyjazne dla użytkownika formaty"17.

W perspektywie rozwoju technologii sieci semantycznej, będącej projektem - analizowanego otwarcie i z nadzieją także na gruncie bibliotekoznawstwa - Webu 3.0, gdzie o dystrybucji informacji mówi się w aspekcie aktualnych, zmiennych i intuicyjnych potrzeb użytkowników, konstatacja o obecnym osadzeniu w epoce post-MARC-owej wydaje się rozsądną i roz-

15 Zob. informacje zawarte na stronie Biblioteki Narodowej, umieszczone w materiałach dla bibliotekarzy w zakładce Historia MARC, http://www.bn.org.pl/dla-bibliotekarzy/nfs/ marc/historia-marc (dostęp 15 czerwca 2017).

16 Zob. R. Tennant, MARC Must Die, "Library Journal”, http://lj.libraryjournal.com/ 2002/10/ljarchives/marc-must-die/\# (dostęp 15 czerwca 2017).

17 J. Pacek, Bibliografia w XXI wieku, [w:] Bibliologia i informatologia, pod red. D. Kuźminy, Warszawa 2011, s. 274. 


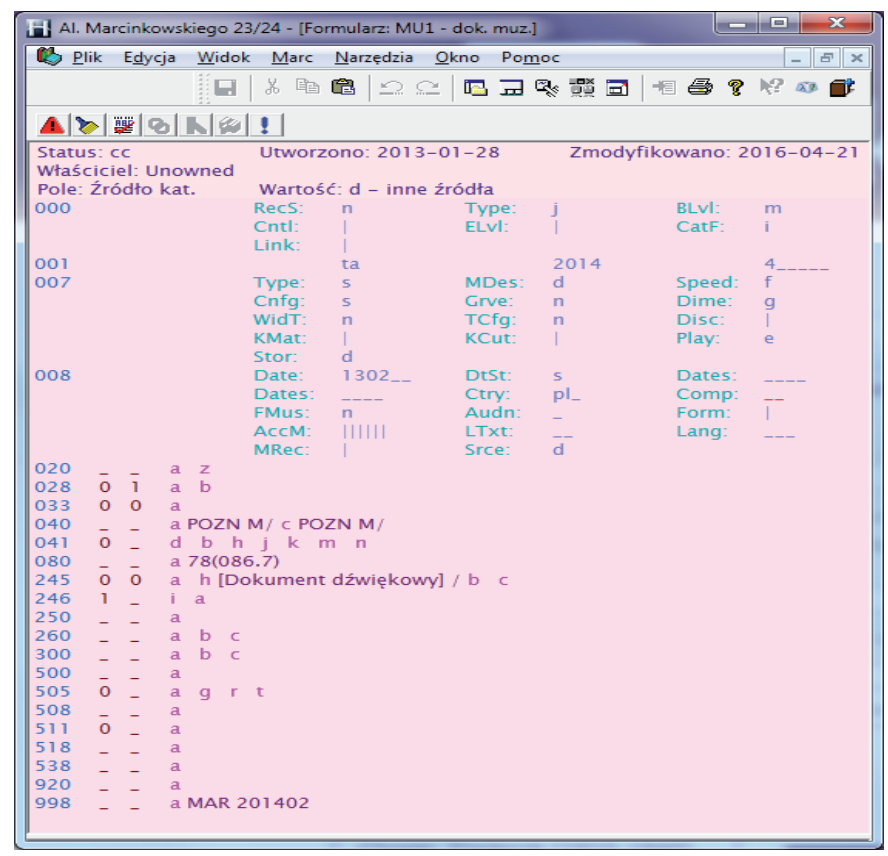

Rys. 3. Niewypełniony formularz formatu MARC 21 dla dźwiękowych zbiorów muzycznych. Formularz nie zawiera pól kontrolowanych kartoteką wzorcową, które w całości należy sprowadzić z bazy

wojową oceną rzeczywistości ${ }^{18}$, mimo iż wciąż MARC 21 jest standardowo wykorzystywanym i ewentualnie aplikowanym do nowego oprogramowania formatem.

Katalogerzy Biblioteki Raczyńskich w sporządzaniu rekordów opisu bibliograficznego posługują się formatem MARC od początku funkcjonowania w komputerowym systemie Horizon.

18 O nadchodzącej epoce post-MARC pisał już w 2005 r. P.-Y. Duchemin, L'enrichissement des catalogues? Et aprés?, "Bulletin des Bibliotheques de France” 2005, nr 4, s. 21-27. Na gruncie polskim w 2006 r. Marek Nahotko, analizując kwestię wizji pożądanej struktury katalogu, który powinien w sposób hierarchiczny i relacyjny porządkować opisywaną rzecz, zauważał: „Wielu bibliotekarzy dostrzega tę potrzebę i uważa, że możliwości takie może dać tylko format inny niż MARC", M. Nahotko, Opis dokumentów elektronicznych. Teoretyczny model i możliwości jego aplikacji, Kraków 2006, s. 122. W 2013 r. Roy Tennant ogłosił kilkuczęściowy tekst zatytułowany The Post-MARC Era, http://www.thedigitalshift.com/2013/04/roy-tennant-digital-libraries/thepost-marc-era-part-1/; http:/ / www.thedigitalshift.com/2013/05/roy-tennant-digital-libraries / the-post-marc-era-part-2/; http://www.thedigitalshift.com/2013/05/roy-tennant-digital-libra ries/the-post-marc-era-part-2-where-the-problems-lie-part-2/; http://www.thedigitalshift.com /2013/06/roy-tennant-digital-libraries/the-post-marc-era-part-2-part-3-inconsistencies/ (dostęp 15 czerwca 2017). 


\section{Dwa standardy języka haseł przedmiotowych na gruncie polskim}

Od samego początku funkcjonowania bibliotek mówić można o metodycznym typowaniu nadrzędnych kategorii nazewniczych w celu zamierzonego segregowania, klasyfikowania i lokalizowania bibliotecznych zbiorów. W praktyce tej, która zyskiwała coraz więcej precyzji, doszło do takiego wewnętrznego uporządkowania, że pewne ustrukturyzowane zbiory hasłowe dekodujące treść i formę postrzegać zaczęto jako odrębne systemy językowe, cechujące się nie tylko semantyką, ale też własną syntaktyką, i włączono je do klasy języków sztucznych jako tzw. języki informacyjno-wyszukiwawcze.

Pośród języków informacyjno-wyszukiwawczych w skali polskiego bibliotekarstwa historycznie najważniejsze znaczenie miały wypracowane $\mathrm{w}$ środowisku warszawskim dwa niezależne języki haseł przedmiotowych: język haseł przedmiotowych KABA i stosowany w bibliografii bieżącej oraz bibliotekach publicznych (w tym w Bibliotece Raczyńskich) język haseł przedmiotowych Biblioteki Narodowej (JHP BN), 1 stycznia 2017 r. zastąpiony w Bibliotece Narodowej nowymi zasadami opracowania - deskryptorami BN (DBN). Języki te są wewnętrznie uporządkowanymi systemami organizowania leksyki w pogrupowane struktury nadrzędno-podrzędne w celu precyzyjnego i optymalnego odzwierciedlenia cech treściowych oraz formalnych zgromadzonych w bibliotekach dokumentów.

\section{KABA (Katalogi Automatyczne Bibliotek Akademickich)}

Język haseł przedmiotowych KABA wykorzystywany jest w bibliotekach akademickich współpracujących (czynnie bądź biernie) z Narodowym Uniwersalnym Katalogiem Centralnym (NUKAT). Swą historią sięga początku lat 90. XX w. i od zarania traktowany był jako wspólny język bibliotek uczelnianych $^{19}$. Przy jego tworzeniu wzięto pod uwage praktykę paryskiej Biblioteki Narodowej, zdobytą przy tworzeniu języka haseł przedmiotowych RAMEAU (Répertoire d'Autorité Matière Encyclopédique et Alphabétique Unifié). Leksyka KAB-y, obecnie rozciągnięta do wieluset tysięcy jednostek, kontrolowana jest hasłami wzorcowymi i zawiera odpowiedniki francuskie oraz angielskie - zgodne ze standardami tych języków, co sprzyja umiędzynarodowieniu opisów i ich osadzeniu w światowym systemie wyszukiwawczym.

Istotną kwestią z perspektywy katalogera Oddziału Opracowania Multimediów Biblioteki Raczyńskich jest fakt wprowadzenia w środowisku KAB-y procesu integracji haseł tytułowych, osobowych i korporaty wnych, które wcześniej pełniły odrębne funkcje - hasła opisu bibliograficznego i tematu w haśle przedmiotowym. Wprawdzie Biblioteka Raczyńskich nie współuczestniczy w tworzeniu bazy katalogowej NUKAT ani nie wykorzystuje języka

${ }^{19}$ Wykorzystuję tu informacje zawarte w artykule A. Stanis, U progu zmian w językach haset przedmiotowych w Polce, „Bibliotekarz” 2015, nr 9, s. 4-12. 
haseł przedmiotowych KABA, jednak posługuje się kartoteką haseł wzorcowych i korzysta z NUKAT-owej struktury tytułu ujednoliconego autorskiego utworu muzycznego. Fakt posługiwania się w Bibliotece Raczyńskich odrębnym językiem haseł przedmiotowych Biblioteki Narodowej, przy jednoczesnym wykorzystaniu konfiguracji zastosowanej w haśle tytułu ujednoliconego (ustandaryzowanego w środowisku NUKAT-owym), może poskutkować (i rzeczywiście tak się raz po raz dzieje) nietożsamym słownictwem w obrębie tego samego rekordu opisu. Jest to naturalną konsekwencją przyjęcia niejako hybrydowego modelu opisu bibliograficznego.

\section{Język haseł przedmiotowych Biblioteki Narodowej (JHP BN)}

Historia języka haseł przedmiotowych BN jest dłuższa niż języka KABA i sięga połowy XX w. W 1989 r. ukazało się pierwsze wydanie Stownika języka haset przedmiotowych Biblioteki Narodowejej ${ }^{20}$, który następnie kilkukrotnie był wznawiany i aktualizowany, a w 2013 r. opublikowany w wersji elektronicznej wraz z bazą ekwiwalentów anglojęzycznych dla części haseł. Wszystkie hasła JHP BN objęte zostały kontrolą kartoteki wzorcowej, zorganizowanej w strukturę "temat" i „określnik". Baza ta od 1 stycznia 2017 r. jest już bazą archiwalną w związku z wprowadzeniem w Bibliotece Narodowej systemu deskryptorów. W Bibliotece Raczyńskich dotychczas nie powzięto jeszcze decyzji o przejściu na DBN-y i wciąż wykorzystuje się bazę JHP BN.

JHP BN jest językiem uniwersalnym, czyli umożliwia odwzorowanie wszystkich elementów treściowych i formalnych danego dzieła i to potencjalnie każdego dzieła (tak np. słownictwo dotyczące muzykaliów stanowi tu jedynie niewielki procent). Konstrukcję leksyki oparto na uznanych, rzetelnych źródłach, wprowadzone słownictwo dookreślone zostało względem wyrażeń homonimicznych - np. hasła: 'Polonez (muz.)' i 'Polonez (samochody osobowe)', a synonimy ustrukturyzowane w system odsyłaczy do hasła głównego.

Podstawowe jednostki strukturalne JHP BN - tematy (rzeczowe, jednostkowe, formalne) - są samodzielne leksykalnie i składniowo, co oznacza, że mogą funkcjonować jako niezależne, odrębne hasła przedmiotowe (hasła proste); określniki natomiast (rzeczowe, geograficzne, chronologiczne) są elementami niesamodzielnymi, stanowią wraz z tematem każdorazowo integralną część hasła jako jednostki podrzędne, dookreślające i precyzujące temat (hasła rozwinięte $)^{21}$. Opis przedmiotowy danego dzieła, umieszczony w konkretnych polach rekordu bibliograficznego, może zawierać jedno na różny

${ }^{20}$ Wówczas w opracowaniu Ewy Stępniak i Jadwigi Trzcińskiej. Zob. Stownik haset przedmiotowych Biblioteki Narodowej na podstawie "Stownika tematów dla bibliografij i katalogów w układzie przedmiotowym" Jana Kossonogi, oprac. E. Stępniak, J. Trzcińsk, Warszawa 1989.

${ }^{21}$ Por. materiały metodyczne BN dla bibliotekarzy: Jezzyk haset przedmiotowych Biblioteki Narodowej. II. Jednostki leksykalne JHP BN, http://www.bn.org.pl/download/document/ 1280922119.pdf (dostęp 16 czerwca 2017). 
sposób ustrukturyzowane hasło przedmiotowe, może też tych haseł liczyć kilka, a nawet kilkanaście. W zależności od budowy haseł (ich liczby i liczby określników w pojedynczym haśle) opis przedmiotowy może przybrać charakter raz bardziej wertykalny, raz bardziej poziomy. W systemie zautomatyzowanym czynnik ów ma wpływ na grupowanie i moc wyszukiwawczą w opcji prostej i zaawansowanej, np. jako słowa kluczowe. Ta właśnie kwestia była jedną z przyczyn rozważenia zmiany gramatyki języka haseł przedmiotowych BN, a następnie powzięcia decyzji o odstąpieniu od niego na rzecz deskryptorów Biblioteki Narodowej.

\section{Deskryptory Biblioteki Narodowej (DBN)}

W wykładzie otwierającym konferencję Deskryptory Biblioteki Narodowej. Propozycja zmian w opracowaniu zbiorów bibliotecznych $w$ dobie sieci semantycznej, 20-21 kwietnia 2015 r. dyrektor Biblioteki Narodowej Tomasz Makowski, informował: „Badania światowe pokazują, że poniżej jednego proc. użytkownicy rozpoczynają kwerendę od serwisów bibliotecznych. Coś, co wydawało się jeszcze w latach 80. i 90. niemożliwe - kwerendy rozpoczynały się od serwisów bibliotecznych"22.

O tym, że rzeczywistość cywilizacji informacyjnej pokolenia Google zdecydowanie wyprzedziła te możliwości dotarcia do informacji, jakie oferowały biblioteki, zdano sobie sprawę już dawno. Nieprzecenionym atutem bibliotek wciąż pozostają jednak zbiory i by je $\mathrm{w}$ tej cywilizacji zachować, a nieraz wręcz do niej "obudzić”, potrzebne są odpowiednie narzędzia wyszukiwawcze. Z pewnością rację ma Zbigniew Zakrzewski, gdy pisze: „Wydaje się, że przyszłość będzie należała do tych współtwórców rynku informacji, którzy nie tylko zdołają zindeksować i skatalogować jak największą liczbę istotnych zasobów sieci, ale też udostępnią skuteczne i intuicyjne ich wyszukiwanie" 23 .

Skoro rzeczywistość jest taka, że - mimo wypracowania języków informacyjno-wyszukiwawczych o gruntownym metodologicznym podłożu - biblioteki przegrywają $\mathrm{w}$ starciu z powszechnymi wyszukiwarkami internetowymi w ten sposób, iż tylko znikomy odsetek użytkowników Internetu rozpoczyna poszukiwanie informacji od katalogów bibliotecznych, to przede wszystkim jest to praktyczna informacja o samych tych indeksach. Zdano sobie sprawę, że biblioteczne katalogi komputerowe są w zasadzie częstokroć jedynie elektronicznymi wersjami katalogów kartkowych i w kontekście

22 Zapis wideo konferencji dostępny na stronie Biblioteki Narodowej, http:/ / www.bn.org. pl/deskryptory/ wystapienia---zapis-wideo (dostęp 16 czerwca 2017).

${ }^{23}$ Z. Zakrzewki, Dokumenty elektroniczne jako nowe pole kooperacji bibliotek oraz pole doświadczalne dla nowych standardów opracowania, [w:] Dylematy opracowania. Materiały V Ogólnopolskiej Konferencji Naukowej zorganizowanej przez Bibliotekę Główna Uniwersytetu Szczecińskiego, Szczecin, 18-20 września 2013 r., pod red. U. Ganakowskiej i M. Różyckiej, Szczecin 2014, s. 72. 
możliwości technologicznych pozostają nierzadko „nieme”. „Z badania, które pod koniec ubiegłego stulecia zostało przeprowadzone na użytkownikach elektronicznych katalogów typu OPAC dziewięćdziesięciu ośmiu bibliotek w USA i Kanadzie, wynikało, że wśród czynników jakościowych mających wpływ na wybór bazy zasobów bibliotecznych, z jakiej korzystają czytelnicy, ogromne znaczenie - poza oczywistym: przydatnością i unikalnością jej zasobów - mają łatwość korzystania w rozumieniu przeszukiwania dostępnych treści - intuicyjność i łatwa nawigacja interfejsu oraz zrozumiałe hasła wyszukiwawcze" ${ }^{24}$.

Złożoność semantyczna języka haseł przedmiotowych, rozbudowana struktura gramatyczna i niepełne oznaczenie relacji były powodem powzięcia decyzji o zaimplementowaniu w Bibliotece Narodowej nowych narzędzi służących opracowaniu zbiorów bibliotecznych - deskryptorów ${ }^{25}$. Deskryptor rozumiany tu ,jako preferowany termin służący do wyrażania pojęć i cech publikacji" 26 (lub po prostu: najbardziej adekwatne określenie) - ma każdorazowo $\mathrm{w}$ relacji $\mathrm{z}$ innymi deskryptorami umożliwić prezentację informacji w sposób możliwie pełny, uproszczony, intuicyjny i zrozumiały dla współczesnego użytkownika. Idea deskryptorów - teoretycznie wsparta solidną bazą nauk informatycznych, językoznawstwa czy filozofii języka, w praktyce łączy się z rezygnacją $\mathrm{z}$ haseł złożonych, ustrukturyzowanych $\mathrm{w}$ podrzędne podpola na rzecz haseł prostych, wyrażonych $w$ formie najbardziej zadomowionej w języku polskim, zwykle w szyku naturalnym, z dopuszczalnym ciągiem kilkuwyrazowym (np. jeden deskryptor dziedzinowy: Bibliotekarstwo, archiwistyka, muzealnictwo). Jeden deskryptor niesie porcję informacji jednego typu, pęk zaś różnych deskryptorów ma każdorazowo precyzyjnie oddawać różne cechy opisywanego dokumentu. Mówi się tu o wyborze słownictwa prostszego, zdroworozsądkowego, wykorzystywanego $\mathrm{w}$ codziennym języku. W systemie zautomatyzowanym przy tego typu narzędziach każda $\mathrm{z}$ relewantnych jednostek - encji, powiązana wzajemne siatką relacji, stanowi samodzielny punkt dostępu, co wiąże się z możliwością tworzenia dowolnych opcji wyszukiwawczych i wyjściem poza sztywne ramy tego, co siłą rzeczy do zaproponowania miały katalogi manualne.

Postulat granulacji danych (niełączenia treści różnego typu) pociąga za sobą konieczność przemodelowania formatu MARC 21 i wprowadzenia do niego nowych pól, które każdorazowo lokują dany rodzaj informacji w jednym, oddzielnym miejscu (w JHP BN gros z nich umieszczonych jest w hory-

${ }^{24}$ C. Tenopir, E.J. Read, Database Use Patterns in Public Libraries, "Reference and User Service Quarterly" 2000, t. 40, nr 1, s. 44-47. Cyt. za M. Cichoń, J. Kalinowski, G. Federowicz, Katalogowanie oparte na encjach, „Rocznik Biblioteki Narodowej” 2014, r. XLV, s. 156.

${ }^{25}$ Zob. materiały metodyczne na stronie BN, http://przepisy.bn.org.pl/deskryptory/za sady-tworzenia-deskryptorow-bn (dostęp 16 czerwca 2017).

${ }^{26}$ M. Cichoń, J. Kalinowski, G. Federowicz, dz. cyt., s. 169. 
zontalnej strukturze pojedynczego hasła w postaci doprecyzowujących określników). To z kolei łączy się z koniecznością respektowania elementów nowego standardu katalogowania RDA (Resource Description and Access), który wpleciony zostaje $\mathrm{w}$ wykorzystywany dotychczas standard ISBD (International Standard Bibliographic Description), dając model rekordu hybrydowego ${ }^{27}$.

Zapowiadane już od kilku lat przejście Biblioteki Narodowej na deskryptory było w tej instytucji procesem stopniowym, odbywającym się przy wtórze dyskusji, warsztatów i konferencji. Ostatecznie zostało uskutecznione z początkiem $2017 \mathrm{r}$. Ponieważ wprowadzenie nowego paradygmatu opisu bibliograficznego łączy się ze znaczną zmianą w katalogowaniu, w Bibliotece Raczyńskich postanowiono na razie nie wprowadzać nowych zasad, poprzestając na dotychczasowym trybie opracowania zbiorów z wykorzystaniem JHP BN. Fakt, że Biblioteka Narodowa jest dla poznańskiej książnicy jednostką wzorcową, a także świadomość wymogów współczesnych standardów światowych w zakresie katalogowania, każą jednak śledzić rozwój wydarzeń, przyglądać się powstającym rekordom i analizować dystrybuowane materiały metodyczne z perspektywą powzięcia decyzji o ewentualnej implementacji DBN-ów w Bibliotece Raczyńskich w bliższej lub dalszej przyszłości ${ }^{28}$.

Z pewnością na uwagę zasługuje też fakt, że deskryptory BN dają nadzieję wprowadzenia jednego standardu języka w bibliotekach wykorzystujących dotychczas JHP BN i KAB-ę. Już 5 października 2015 r., podczas III Seminarium Członków Zarządu Okręgu Małopolskiego SBP Z polskiego na nasze - perspektywy rozwoju opracowania przedmiotowego w Polsce, kwestię tę rozważali zarówno przedstawiciele Biblioteki Narodowej, jak i reprezen-

27 Zob. tamże, s. 160-161.

28 Zauważyć należy, że w przypadku muzykaliów już obecne hasła przedmiotowe mają strukturę podobną do tych, które przewiduje się dla deskryptorów. Opracowując zbiory muzyczne, w zdecydowanej większości nie wprowadza się haseł rzeczowych (zasadniczo nie tematuje się treści utworów, chyba że dany tytuł płyty zdecydowanie za tym przemawia, np. Piosenki $o$ Warszawie, wtedy wprowadza się hasło główne 'Warszawa' z określnikiem 'w muzyce' ), a jedynie hasła formalne (identyfikujące typ, gatunek i formę muzyczną, np. 'Kwartet smyczkowy', 'Muzyka fortepianowa') i hasła określające przynależność kulturowo-etniczną (np. 'Muzyka polska'), dodając każdorazowo określnik chronologiczny w podpolu y. Konwersja strukturalna w obrębie haseł przedmiotowych w razie przyjęcia zasad DBN-ów będzie się wiązała głównie z likwidacją określnika chronologicznego i przeniesieniem tych danych do odpowiedniego pola kodującego czas powstania dokumentu (pole 388), zasadnicze hasło - deskryptor formalny pozostanie w zasadzie bez zmian. Oczywiście uwzględnić trzeba też konieczność wprowadzenia dodatkowych pól, informujących np. o typie odtwarzania, typie zawartości czy typie nośnika, czego dotychczas się nie robi, oraz mieć na uwadze, iż zasady wprowadzone do DBN-ów nie obejmują jedynie haseł przedmiotowych, ale też określają inne parametry - np. formę wzorcową dla haseł osobowych czy korporatywnych. Kwestie te nie zmieniają faktu, że w przypadku ewentualnego przejścia z języka haseł przedmiotowych na deskryptory BN katalogerzy opracowujący muzykalia w Bibliotece Raczyńskich borykać będą się z mniejszymi trudnościami niż osoby opracowujące inny typ dokumentów. 
tanci bibliotek akademickich oraz Centrum NUKAT ${ }^{29}$. Fakt istnienia dwóch standardów języka haseł przedmiotowych jest od lat postrzegany jako czynnik niekorzystny dla rozwoju polskiego bibliotekarstwa, w kontekście włączania się ośrodków państwowych w porządkowanie globalnych danych rzec można - tym bardziej niewdzięczny. Szansa istnienia jednolitych haseł wzorcowych w skali całego kraju nabiera jeszcze innego kolorytu w kontekście takiej perspektywy, jaką przed ponad dekadą wysuwała Maria Burchard, mówiąc o bazie NUKAT-owej: „[Zbiór rekordów kartoteki haseł wzorcowych - A.S] ma znaczenie szczególne. Zgromadzone w nim ujednolicone nazwy osobowe, nazwy ciał zbiorowych nie powinny być kojarzone wyłącznie z katalogami bibliotecznymi. Mają one bowiem wymiar uniwersalny i powinny być wykorzystywane jako klucze dostępu do różnego rodzaju baz informacyjnych, w przyszłości także baz archiwalnych i muzealnych. Jest to jeden ze sprawdzonych sposobów panowania nad chaosem i zapewnienia kompleksowej odpowiedzi na pytania zadawane przez coraz bardziej wymagającego użytkownika" ${ }^{\prime 30}$.

Jakkolwiek decyzja Biblioteki Narodowej o wprowadzeniu deskryptorów nie zawsze spotykała się z uznaniem i aprobatą ${ }^{31}$, trzeba przyznać, że jest postanowieniem odważnym, wpisującym się $\mathrm{w}$ nowoczesne rozwiązania światowe. Bibliotekarze Biblioteki Raczyńskich mają tego pełną świadomość. Niezwykle obiecującą perspektywą w kontekście koncentracji danych pochodzących $\mathrm{z}$ wielu źródeł jest $\mathrm{w}$ tym momencie także proponowany przez Bibliotekę Narodową projekt wdrożenia multiwyszukiwarki OMNIS, którego realizacja przewidziana jest do roku 201932. Projekt ów jest częścią większego przedsięwzięcia „E-usługa OMNIS”, zakładającego udostępnienie jeszcze trzech innych narzędzi: repozytorium wydawniczego e-ISBN ${ }^{33}$, Polony

${ }^{29}$ Sprawozdanie z konferencji zamieszczone zostało na stronie Biblioteki Jagiellońskiej, http://www.bj.uj.edu.pl/aktualnosci/-/journal_content/56_INSTANCE_yKyXBcPe4BIx/ 4148353/104019418 (dostęp 16 czerwca 2017).

${ }^{30}$ M. Burchard, Narodowy Uniwersalny Katalog Centralny NUKAT a przemiany w bibliotekach, [w:] Biblioteki naukowe w kulturze i cywilizacji, działania i codzienność. Materiaty konferencyjne, Poznań, 15-17 czerwca 2005, T. 1, pod red. Haliny Ganińskiej, Poznań 2005, s. 188 [online], http:/ / library.put.poznan.pl/2005/pdf/4_2.pdf (dostęp 16 czerwca 2017).

${ }^{31}$ Zob. np. tekst osoby zaangażowanej w rozwój JHP BN, która krytycznie odnosi się do zmian w opracowaniu przedmiotowym i koncepcji deskryptorów: A. Stolarczyk, Deskryptory Biblioteki Narodowej - niepokoje bibliotekarza praktyka, „Biuletyn EBIB” 2015, nr 5 (158) [online], http://open.ebib.pl/ojs/index.php/ebib/article/viewFile/361/528 (dostęp16 czerwca 2017).

32 Zob. informację na stronie BN, http://www.bn.org.pl/omnis/o-projekcie/ (dostęp 16 czerwca 2017).

${ }^{33}$ Będzie to jednolita baza informująca o rynku wydawniczym - stanie aktualnym, publikacjach planowanych i o nakładzie wyczerpanym. 
w Chmurze dla bibliotek ${ }^{34}$ i Polony w Chmurze dla naukowców ${ }^{35}$. Wszystkie te usługi - co należy podkreślić - przedstawiane są jako propozycje bezpłatne, a do partycypacji w nich zaproszone są nie tylko biblioteki, ale też inne instytucje kultury, jak muzea czy archiwa ${ }^{36}$. Wdrożenie multiwyszukiwarki, która zapewni zintegrowane przeszukiwanie katalogów bibliotecznych z całego kraju oraz wybranych inwentarzy archiwów i muzeów, dawałaby szansę nie tylko pełniejszej realizacji zapisu ustawy o bibliotekach na temat spójnej i jednolitej ogólnokrajowej sieci bibliotecznej ${ }^{37}$, ale też wpisywałoby się w szerszy kontekst międzyinstytucjonalnej wymiany metadanych. Wyszukiwarka OMNIS zaadoptowana zostanie do środowiska MARC 21, a dla pracowników Biblioteki Raczyńskich istotne jest też to, że pozyskanie danych będzie odbywać się z bazy różnorodnych systemów (w tym wykorzystywanego dotychczas w poznańskiej książnicy Horizona). Oparcie na modelu linked data i indeksacja w Googlu w sposób zasadniczy zmieni pozycję opisów bibliograficznych, które z izolowanych informacji o pojedynczym dokumencie staną się częścią globalnej sieci danych.

Świadomość powiększającej się liczby zbiorów multimedialnych, modyfikacji nawyków czytelniczych (audiobooki) i poszerzania oferty udostępnianych zbiorów bibliotecznych (filmy na DVD) pozwala w tym kontekście popatrzeć także na pracę katalogera Oddziału Opracowania Multimediów Biblioteki Raczyńskich jako pełnoprawnego dostawcę coraz większego zasobu globalnych danych dostępnych dla każdego w Internecie, a nie tylko dla potencjalnego eksploratora bibliotecznego katalogu umieszczonego na stronie biblioteki. Czas, by kimś takim kataloger już się stał!

\section{Bibliografia}

\section{Źródła drukowane i rękopiśmienne}

5 lat Poznańskiej Fundacji Bibliotek Naukowych, Poznań 2001.

Bibliologia i informatologia, pod red. D. Kuźminy, Warszawa 2011.

Cichoń M., Kalinowski J., Federowicz G., Katalogowanie oparte na encjach, „Rocznik Biblioteki Narodowej" 2014, r. XLV.

Drożdż A., Stachyra M., Format MARC 21 rekordu bibliograficznego dla dokumentu dźwiękowego, Warszawa 2002.

34 Umożliwiającej instytucjom zarządzanie własną bazą cyfrową (z zachowaniem tożsamości) w repozytorium Biblioteki Narodowej.

${ }^{35} \mathrm{~W}$ ramach tego modułu naukowcy zyskają możliwość publikacji tekstów w Polonie i wzajemną komunikację.

${ }^{36}$ Zob. informację na stronie BN, http://www.bn.org.pl/aktualnosci/1305-inauguracjaprojektu-biblioteki-narodowej-e-usluga-omnis.html (dostęp 16 czerwca 2017).

${ }^{37}$ Por. art. 27 i 28 Ustawy z dnia 27 czerwca 1997 r. o bibliotekach, http://prawo.sejm. gov.pl/isap.nsf/download. $x$ sp?id=WDU19970850539\&type=O\&name=D19970539.pdf (dostęp 16 czerwca 2017). 
Duchemin P.-Y., L'enrichissement des catalogues? Et aprés?, „Bulletin des Bibliotheques de France” 2005, nr 4.

Dylematy opracowania. Materiały V Ogólnopolskiej Konferencji Naukowej zorganizowanej przez Bibliotekę Główna Uniwersytetu Szczecińskiego, Szczecin, 18-20 września 2013 r., pod red. U. Ganakowskiej i M. Różyckiej, Szczecin 2014.

Karwasiński P., Wesołowska-Mis H., Wptyw informatyzacji Biblioteki Uniwersyteckiej w Poznaniu na zmiany organizacyjne i rozwój ustug bibliotecznych, „Biblioteka” 2015, nr 19(28).

Nahotko M., Opis dokumentów elektronicznych. Teoretyczny model i możliwości jego aplikacji, Kraków 2006.

Sanetra, Format MARC 21 rekordu bibliograficznego dla dokumentu elektronicznego, Warszawa 2003.

Sanetra, Format MARC 21 rekordu bibliograficznego dla filmu, Warszawa 2008.

Stownik haset przedmiotowych Biblioteki Narodowej na Podstawie "Stownika tematów dla bibliografij i katalogów w układzie przedmiotowym" Jana Kossonogi, oprac. E. Stępniak, J. Trzcińska, Warszawa 1989.

Stanis A., U progu zmian w jezykach haset przedmiotowych w Polce, „Bibliotekarz” 2015, nr 9.

Statut Biblioteki Raczyńskich, rkp. Dział Zbiorów Specjalnych Biblioteki Raczyńskich, sygn. Rkp. 124.

\section{Źródła internetowe}

Breeding M., Perceptions 2016: An International Survey of Library Automation, https:/ / librarytech nology.org/perceptions/2016/\#survey-details (dostęp 15 czerwca 2017).

Burchard M., Narodowy Uniwersalny Katalog Centralny NUKAT a przemiany w bibliotekach, [w:] Biblioteki naukowe w kulturze i cywilizacji, dziatania i codzienność. Materiaty konferencyjne, Poznań, 15-17 czerwca 2005, t. 1, pod red. H. Ganińskiej, Poznań 2005, http://library.put. poznan.pl/2005/pdf/4_2.pdf (dostęp 16 czerwca 2017).

Ciesielska-Kruczek R., Fogla A., Kołakowska J., Systemy biblioteczne nowej generacji. Platformy usług - sprawozdanie z konferencji Biblioteki Głównej Politechniki Śląskiej, „Biblioteka i Edukacja. Elektroniczne czasopismo Biblioteki Głównej Uniwersytetu Pedagogicznego w Krakowie" 2015, nr 8, www.bg.up.krakow.pl/newbie/index.php/bie/article/download/126/126 (dostęp 10 czerwca 2017).

Deskryptory Biblioteki Narodowej. Propozycja zmian w opracowaniu zbiorów bibliotecznych w dobie sieci semantycznej, 20-21 kwietnia 2015 r. Zapis wideo konferencji, http://www.bn.org.pl/ deskryptory/wystapienia---zapis-wideo (dostęp 16 czerwca 2017).

Hejda A., Szczęsny P., Habis, A., Aktywna biblioteka. Multimedia i nowoczesna komunikacja, Warszawa 2010, https://issuu.com/publikacjefrsi/docs/nowowczesna-komunikacja (dostęp 10 czerwca 2017).

Stolarczyk A., Deskryptory Biblioteki Narodowej - niepokoje bibliotekarza praktyka, „Biuletyn EBIB” 2015, nr 5(158), http://open.ebib.pl/ojs/index.php/ebib/article/viewFile/361/528 (dostęp 16 czerwca 2017).

Tennant R., MARC Must Die, “Library Journal”, http://lj.libraryjournal.com/2002/10/ ljarchives/marc-must-die/\#_(dostęp 15 czerwca 2017).

Tennant R., The Post-MARCEra,http:/ / www.thedigitalshift.com/2013/04/roy-tennant-digital-libraries/the-post-marc-era-part-1/; http://www.thedigitalshift.com/2013/05/roy-tennantdigital-libraries/the-post-marc-era-part-2/; http:/ / www.thedigitalshift.com/2013/05/roytennant-digital-libraries/the-post-marc-era-part-2-where-the-problems-lie-part-2/; http:/ / www.thedigitalshift.com/2013/06/roy-tennant-digital-libraries/the-post-marc-era-part-2part3-inconsistencies/ (dostęp 15 czerwca 2017).

http:/ / prawo.sejm.gov.pl/isap.nsf/download.xsp?id=WDU19970850539\&type=O\&name=D1 9970539.pdf (dostęp 16 czerwca 2017). 
Strony baz bibliotek

http:/ / www.bj.uj.edu.pl/aktualnosci/-/journal_content/56_INSTANCE_yKyXBcPe4BIx/ 4148353/104019418 (dostęp 16 czerwca 2017).

http:/ / przepisy.bn.org.pl/deskryptory / zasady-tworzenia-deskryptorow-bn (dostęp 16 czerwca 2017).

http:/ / www.bn.org.pl/dla-bibliotekarzy/nfs/marc/historia-marc (dostęp 15 czerwca 2017).

http:// www.bn.org.pl/download/document/1280922119.pdf (dostęp 16 czerwca 2017).

http://www.bn.org.pl/omnis/o-projekcie/ (dostęp 16 czerwca 2017).

http://www.bn.org.pl/aktualnosci/1305-inauguracja-projektu-biblioteki-narodowej-e-uslugaomnis.html (dostęp 16 czerwca 2017).

Alicja Sobańska

\title{
Oddział Opracowywania Multimediów Biblioteki Raczyńskich w Poznaniu - struktura, zadania, baza programowa
}

\section{Streszczenie}

W tekście przedstawiono Oddział Opracowania Multimediów poznańskiej Biblioteki Raczyńskich z uwzględnieniem kilku parametrów: postępowania z przynależnymi zbiorami na nośnikach cyfrowych (audiobooki, filmy, muzyka, inne dokumenty elektroniczne), wykorzystywanego systemu bibliotecznego (Horizon), stosowanego formatu metadanych (MARC 21), będącego w użytku języka haseł (JHP BN) na tle języka KABA i deskryptorów Biblioteki Narodowej.

Słowa kluczowe: Biblioteka Raczyńskich, Oddział Opracowania Multimediów, obieg zbiorów, system biblioteczny Horizon, format MARC 21, język KABA, język haseł przedmiotowych BN, deskryptory BN

\section{The Department of Multimedia Processing at the Raczyński Library in Poznan - structure, tasks, and agenda}

\begin{abstract}
The article discusses the Department of Multimedia Processing at the Raczyński Library in Poznań, highlighting several elements of its activity: management of the Library's collection in digital formats (audio books, films, music, other electronic documents), use of the library system (Horizon), meta data format (MARC 21), the keyword language used at the National Library (JHB BN) compared with the KABA language and descriptors of the National Library.
\end{abstract}

Keywords: Raczyński Library, Department of Multimedia Processing, circulation of the collection, Horizon library system, MARC 21 format, KABA language, keyword language of the National Library, National Library descriptors 